\title{
Platynosomum illiciens (Trematoda: Dicrocoeliidae) in a hybrid marmoset (Callithrix sp.) in the Municipality of Seropédica, RJ, Brazil - Case report
}

\author{
Platynosomum illiciens (Trematoda: Dicrocoeliidae) em um sagui híbrido \\ (Callithrix sp.) no município de Seropédica, RJ, Brasil - Relato de caso
}

Rayane Christine Pereira de Assis ${ }^{1}$; Diefrey Ribeiro Campos ${ }^{1}$; Debora Azevedo Borges ${ }^{1 *}$ (D);

Barbara Rauta de Avelar; julia Aline Santos de Mello Pereira²; Carlos Alexandre Rey Matias²; Carlos Wilson Gomes Lopes ${ }^{3}$; Douglas Mclntosh ${ }^{3}$; Fabio Barbour Scott

\footnotetext{
' Laboratório de Quimioterapia Experimental em Parasitologia Veterinária, Departamento de Parasitologia Animal, Instituto de Veterinária - IV, Universidade Federal Rural do Rio de Janeiro - UFRRJ, Seropédica, Campus Seropédica, RJ, Brasil 2 Departamento de Epidemiologia e Saúde Pública, Instituto de Veterinária - IV, Universidade Federal Rural do Rio de Janeiro -UFRRJ, Campus Seropédica, Seropédica, RJ, Brasil

${ }^{3}$ Departamento de Parasitologia Animal, Instituto de Veterinária - IV, Universidade Federal Rural do Rio de Janeiro - UFRRJ, Campus Seropédica, Seropédica, RJ, Brasil
}

How to cite: Assis RCP, Campos DR, Borges DA, Avelar BR, Pereira JASM, Matias CAR, et al. Platynosomum illiciens (Trematoda: Dicrocoeliidae) in a hybrid marmoset (Callithrix sp.) in the Municipality of Seropédica, RJ, Brazil - Case report. Braz J Vet Parasitol 2021; 30(2): e026020. https://doi.org/10.1590/S1984-29612021012

\begin{abstract}
Platynosomum illiciens is a liver trematode encountered infecting mainly felids although it has also been reported in birds and in additional mammalian species, including non-human primates. The current study reports a natural $P$. illiciens infection primate of the genus Callithrix. The diagnosis was made using a combination of copro-parasitological techniques, morphological evaluation of adult specimens recovered from the liver during necropsy, and molecular analyses. Eggs were brown in color, oval, operculated, and contained a miracidium. Adult specimens recovered during necropsy were measured and showed dimensions compatible with $P$. illiciens. Molecular characterization of the trematode involved amplification by polymerase chain reaction (PCR), in combination with nucleotide sequencing, of an approximately 900 base pairs fragment corresponding to 18S-ITS1$5.8 \mathrm{~S}$ ribosomal DNA. Sequenced amplicons showed 100\% nucleotide identity with sequences deposited in the GenBank database as derived from specimens of $P$. illiciens recovered from cats in Malaysia and Brazil. It was concluded that the morphological and molecular analyses presented herein, confirmed the identification of the trematode recovered as $P$. illiciens.
\end{abstract}

Keywords: Platynosomiasis, parasitological diagnosis, non-human primates.

\begin{abstract}
Resumo
Platynosomum illiciens é um trematódeo do fígado, encontrado principalmente em felinos, embora também tenha sido relatado em aves e outras espécies de mamíferos, incluindo primatas não humanos. Este estudo relata um caso de parasitismo natural por $P$. illiciens em um primata do gênero Callithrix. O diagnóstico foi feito com uma combinação de técnicas coproparasitológicas, avaliação morfológica de espécimes adultos recuperados do fígado durante a necropsia e análise molecular. Os ovos eram de cor marrom, ovais, operculados e continham um miracídio. Espécimes adultos recuperados durante a necropsia foram medidos e mostraram dimensões compatíveis com $P$. illiciens. A caracterização molecular do trematódeo envolveu a reação em cadeia da polimerase (PCR) e o sequenciamento de um fragmento de, aproximadamente, 900 pares de bases correspondentes ao DNA robosomal 18S-ITS1-5.8S, que apresentou $100 \%$ de identidade da sequência de nucleotídeos com as sequências do GenBank depositadas como derivadas de $P$. illiciens recuperados de gatos na Malásia e no Brasil, respectivamente. Concluiu-se pelas análises morfológicas e moleculares aqui apresentadas, que o trematódeo é da espécie $P$. illiciens.
\end{abstract}

Palavras-chaves: Platinosomíase, diagnóstico parasitológico, primatas não humanos. 
Platynosomum illiciens (syn. Platynosomum fastosum, Platynosomum concinnum, Platynosomum amazonensis, Platynosomum marmoseti), is a biliary tract trematode encountered infecting mainly felids although it has been detected in other species of mammal, including non-human primates and also in birds (Rodrigues, 1963; Basu \& Charles, 2014; Pinto et al., 2017). The life cycle begins with embryonated eggs being released in the feces of the definitive host with subsequent ingestion by the first intermediate host, namely terrestrial mollusks of the genera Subulina or Eulota. Miracidia are released and penetrate the connective tissue of the mollusk, wherein the process of cell division of the mother sporocyst to mature daughter sporocysts occurs, resulting in the formation of cercariae. The mature sporocysts containing the cercariae are released from the mollusk and are ingested by a second intermediate host, specifically terrestrial isopods, wherein the cercariae transform into infective metacercariae. Paratenic hosts (reptiles, amphibians) ingest the isopods infected with the metacercariae. Infection of the definitive host occurs via the ingestion of the second intermediate or paratenic hosts containing the metacercaria, which excyst and migrate through the duodenum to the bile ducts and gallbladder, wherein they develop into adults and reproduce, releasing embryonated eggs in the feces (Basu \& Charles, 2014; Pinto et al., 2014).

Most infections of primates with $P$. illiciens are reported as post mortem findings, and as a result the clinical manifestations and process of pathogenesis are poorly understood. However, the diagnosis of platynosomiasis including ante mortem detection of asymptomatic infections can be achieved with the aid of centrifugation-flotation techniques including the use of saturated sucrose solution or via sedimentation with formalin-ether, with the latter being considered more effective (Basu \& Charles, 2014). Confirmation occurs through the observation of brown, operculated eggs in the feces (Bielsa \& Greiner, 1985; Basu \& Charles, 2014). The number of eggs shed within the feces is influenced by the parasitic load, although it is important to consider that flukes of the genus Platynosomum are known to release eggs intermittently (Leal et al., 2011).

The current study reports a case of natural parasitism by $P$. illiciens in an adult female, hybrid marmoset of the genus Callithrix, held at the Center for Screening of Wild Animals (CETAS) in Seropédica, Rio de Janeiro, Brazil. The animal was admitted to the Veterinary Small Animal Hospital, located on the Seropédica Campus of The Federal Rural University of Rio de Janeiro (UFRRJ), with a history of head trauma. Parasitological examination of a stool sample was performed at the Experimental Chemotherapy Laboratory for Veterinary Parasitology (UFRRJ), as a component of the routine clinical protocols.

The fecal sample was evaluated using a centrifugal-flotation method employing sucrose solution (Sloss et al., 1999) and also by formalin-ether sedimentation (Ritchie, 1948). Microscopic examination revealed the presence of brown, oval, operculated eggs with an internal miracidium, indicating they were trematode eggs (Figure 1A). Thereafter, eggs $(n=30)$ were measured using an Olympus SZX16 binocular microscope, with photomicrographs generated via a coupled UC30 camera and analyzed using the cellSens Dimension software. The dimensions of the largest and smallest diameters were $41.24 \mu \mathrm{m}$ (32.62- 46.76) and 28.13 $\mu \mathrm{m}$ (22.05-37.67), respectively, with an average wall thickness of $1.79 \mu \mathrm{m}$.

As reported previously (Basu \& Charles, 2014), the formalin-ether sedimentation technique (Leal et al., 2015) showed greater sensitivity for the recovery of $P$. illiciens eggs from feces than did the centrifugal flotation technique (Sloss et al., 1999). Ritchie (1948) proposed that the enhancement in recovery reflected the fact that heavy eggs, such as those of $P$. illiciens, are more likely to sediment than to float. Nevertheless, it is pertinent to note that the findings of the present study corroborate the observation of Shell et al. (2015), that the centrifugal flotation technique is an effective method for the detection of $P$. illiciens eggs in feces.

Owing to the severe clinical condition resulting from the head trauma and as a consequence of unresponsiveness to treatment, the animal died and was subjected to parasitological necropsy (protocol number; ICMBio/n57694-1). A total of 13 specimens of adult trematodes were encountered in the liver, together with two in the jejunum and two in the gallbladder. Specimens for morphological and morphometric analyses were fixed in acetic formaldehyde at room-temperature, stained with hydrochloric carmine, dehydrated in a series of ascending ethanol solutions (alcohol 70, $90 \mathrm{GL}$ and absolute) and mounted in balsam added to beech-wood creosote according to the procedure of Amato et al. (1991). Microscopic examinations employed an Olympus BX51 binocular microscope, with a coupled UC30 camera and the cellSens Dimension software.

Fragments of liver, jejunum, gallbladder, and lung were placed in petri dishes containing saline solution and observed under a Nikon YS2-T binocular microscope. Thereafter, they were held overnight in Hoffman's goblets in an attempt to recover eggs or larvae. However, no parasitic forms were found in any of the organs examined. In contrast, examination of biliary and fecal contents, collected post mortem, showed the presence of numerous eggs. 


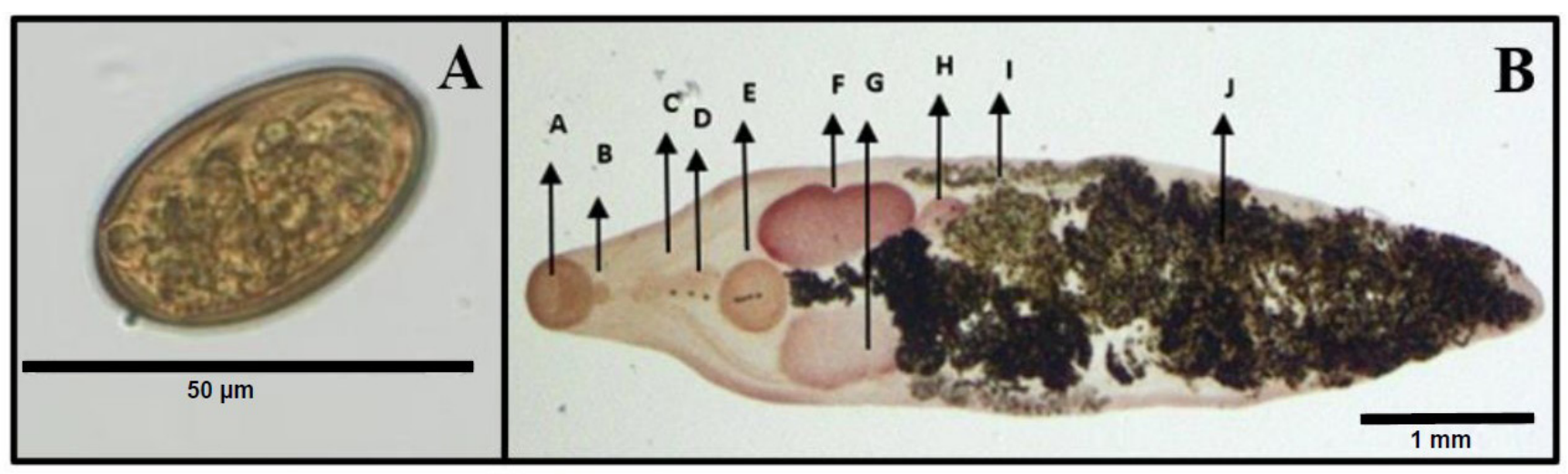

Figure 1. (A) Photomicrograph of an egg of Platynosomum illiciens recovered from feces by the saturated sucrose flotation technique. (B) Photomicrograph, ventral view, of an adult specimen of Platynosomum illiciens recovered from the liver of a marmoset of the genus Callithrix. A: oral sucker; B: pharynx; C: intestinal caeca; D: cirrus pouch; E: acetabulum; F: right testicle; G: left testicle; H: ovary; I: vitellaria; J: uterus. Stained with Hydrochloric carmine.

Adults of $P$. illiciens are characterized by the distribution of the supracecal vitellines in the median region of the body, lobed and opposite testicles, round to lobed ovary (located below the testicles) and, by the acetabulum being slightly larger than the oral sucker (Lenis et al., 2009). Those features were confirmed by the observations recorded in the present report (Figure 1B). The morphological data, obtained for the adult specimens of $P$. illiciens examined herein, were compared (Table 1) with the values provided for proposed species of Platynosomum, recorded by Brazilian researchers, naturally infecting felids and birds (Travassos, 1944), or from non-human primates (Kingston \& Cosgrove, 1967; Pinto et al., 2017). In addition, we included morphological data registered in mice (Mus musculus) artificially infected with P. illiciens (Pinto et al., 2015). The results of those comparisons provided support for the proposition of Pinto et al. (2017) that the parasites employed in the description of the species $P$. amazonensis and P. marmoseti (Kingston \& Cosgrove, 1967) were most likely not fully developed. As such, rather than representing new species, they simply reflected the phenomenon of extensive morphological variation that has been widely documented for specimens of $P$. illiciens infecting different hosts (Travassos, 1944; Rodrigues, 1963; Pinto et al., 2016). Thus, we agree with the recommendation of Pinto et al. (2017) that $P$. amazonensis and $P$. marmoseti should be considered synonyms of $P$. illiciens.

An adult trematode, recovered from the liver, was stored in RNAlater ${ }^{\mathrm{TM}}$ (Ambion) at $-20^{\circ} \mathrm{C}$ for subsequent molecular diagnosis. DNA was extracted using the phenol-chloroform bead-beater protocol reported by Santolin et al. (2013). Amplicons, corresponding to approximately 950 base pairs of the 18S-ITS1-5.8S rDNA, were generated by the polymerase chain reaction (PCR) using the primers (18SF) 5'-CCT GGT AAG TGC AAG TCA GAT GC-3' and (5.8SR) 5'-CAT GGC CGC AAT ATG CTT GCA-3' in combination with the thermocycling conditions reported by Nguyen et al. (2017).

Sequence analysis of duplicate 18S-ITS1-5.8S rDNA amplicons revealed 100\% (841/841 bases) nucleotide identity with the sequences MT015696 and MH156567 deposited in the GenBank as derived from specimens of $P$. illiciens recovered from cat liver in Malaysia and in Brazil, respectively. In addition, the novel sequence was identical to the sequences KU987672 and KU987674 deposited as originating in specimens of $P$. fastosum recovered from cats in Vietnam. Pinto et al. (2018) included the same $P$. fastosum sequences from Vietnam in a comparative analysis of ITS-1 sequences derived from adult specimens of $P$. illiciens recovered from primates and mice, together with sequences generated from metacercariae in geckos. All sequences, with the exception of a single nucleotide polymorphism (SNP) observed in one of the sequences obtained from an experimentally infected mouse, were identical. Those results provided definitive evidence that $P$. illiciens can naturally infect felines and non-human primates as well as rodents experimentally, corroborating the findings of earlier morphological studies (Pinto et al., 2015, 2017). Importantly, the sequencing data demonstrated that Platynosomum infections in cats in the Americas and Asia are caused by the same parasite, substantiating the proposal of Rodrigues (1963), for the recognition of $P$. fastosum and $P$. illiciens as synonyms. As such, the marmoset trematode examined herein was considered to represent $P$. illiciens and the sequence was deposited in the GenBank with accession number MK166042.

Although extensive morphological variability was reported for specimens of $P$. illiciens observed in hosts with natural (Travassos, 1944) or experimental infections (Pinto et al., 2015), factors such as parasite age, the precise 
Table 1. Comparision of morpholoical data reported for adult forms of Platynosomum illiciens encountered in vertebrate hosts in Brazil.

\begin{tabular}{|c|c|c|c|c|c|c|c|c|}
\hline $\begin{array}{l}\text { Definitive } \\
\text { host }\end{array}$ & $\mu \mathrm{m}$ & Felis catus & $\begin{array}{c}\text { Rupornis } \\
\text { magnirostris }\end{array}$ & $\begin{array}{c}\text { Mus } \\
\text { musculus }\end{array}$ & $\begin{array}{l}\text { Callithrix } \\
\text { penicillata }\end{array}$ & $\begin{array}{l}\text { Callimico } \\
\text { goeldii/ } \\
\text { Saguinus } \\
\text { nigricollis }\end{array}$ & S. nigricollis & $\begin{array}{l}\text { Callithrix } \\
\text { sp. }\end{array}$ \\
\hline \multirow[t]{2}{*}{ Body } & Length & $3000-6100$ & $2900-6700$ & $\begin{array}{c}3723 \\
(2235-4986)\end{array}$ & $\begin{array}{c}3975 \\
(1736-7135)\end{array}$ & $\begin{array}{c}3700 \\
(3020-4930)\end{array}$ & $\begin{array}{c}2580 \\
(2150-2880)\end{array}$ & $\begin{array}{c}6013 \\
(5688-6378)\end{array}$ \\
\hline & Width & $1600-6400$ & $900-1700$ & $\begin{array}{c}1362 \\
(860-1719)\end{array}$ & $\begin{array}{c}1175 \\
(602-2063)\end{array}$ & $\begin{array}{c}1280 \\
(990-1720)\end{array}$ & $\begin{array}{c}730 \\
(520-860)\end{array}$ & $\begin{array}{c}1367 \\
(1218-1533)\end{array}$ \\
\hline \multirow[t]{2}{*}{ Oral sucker } & Length & $360-480$ & $420-630$ & $\begin{array}{c}336 \\
(239-423)\end{array}$ & $\begin{array}{c}332 \\
(218-464)\end{array}$ & $\begin{array}{c}392 \\
(300-465)\end{array}$ & $\begin{array}{c}250 \\
(210-270)\end{array}$ & $\begin{array}{c}418 \\
(404-424)\end{array}$ \\
\hline & Width & $360-480$ & $420-630$ & $\begin{array}{c}300 \\
(246-348)\end{array}$ & $\begin{array}{c}310 \\
(225-444)\end{array}$ & $\begin{array}{c}392 \\
(300-465)\end{array}$ & $\begin{array}{c}250 \\
(210-270)\end{array}$ & $\begin{array}{c}409 \\
(377-442)\end{array}$ \\
\hline \multirow[t]{2}{*}{ Pharynx } & Length & $120-150$ & $150-180$ & $\begin{array}{c}124 \\
(82-150)\end{array}$ & $\begin{array}{c}118 \\
(82-171)\end{array}$ & $\begin{array}{c}141 \\
(120-150)\end{array}$ & $\begin{array}{c}93 \\
(72-110)\end{array}$ & $\begin{array}{c}107 \\
(96-114)\end{array}$ \\
\hline & Width & $120-150$ & $150-180$ & $\begin{array}{c}107 \\
(68-137)\end{array}$ & $\begin{array}{c}113 \\
(82-171)\end{array}$ & $\begin{array}{c}141 \\
(120-150)\end{array}$ & $93(72-110)$ & $\begin{array}{c}127 \\
(113-158)\end{array}$ \\
\hline \multirow[t]{2}{*}{ Acetabulum } & Length & $420-540$ & $390-720$ & $\begin{array}{c}327 \\
(253-430)\end{array}$ & $\begin{array}{c}360 \\
(259-498)\end{array}$ & $\begin{array}{c}451 \\
(360-660)\end{array}$ & $\begin{array}{c}288 \\
(222-315)\end{array}$ & $\begin{array}{c}403 \\
(325-443)\end{array}$ \\
\hline & Width & $420-540$ & $390-720$ & $\begin{array}{c}326 \\
(239-396)\end{array}$ & $\begin{array}{c}344 \\
(253-457)\end{array}$ & $\begin{array}{c}451 \\
(360-660)\end{array}$ & $\begin{array}{c}288 \\
(222-315)\end{array}$ & $\begin{array}{c}418(389- \\
444)\end{array}$ \\
\hline Right & Length & $200-960$ & $300-500$ & $\begin{array}{c}599 \\
(355-887)\end{array}$ & $\begin{array}{c}525 \\
(273-990)\end{array}$ & $\begin{array}{c}247 \\
(135-345)\end{array}$ & $\begin{array}{c}393 \\
(300-510)\end{array}$ & $\begin{array}{c}846 \\
(682-1026)\end{array}$ \\
\hline Testicle & Width & $180-720$ & $250-780$ & $\begin{array}{c}395 \\
(232-546)\end{array}$ & $\begin{array}{c}371 \\
(171-683)\end{array}$ & $\begin{array}{c}199 \\
(135-345)\end{array}$ & $\begin{array}{c}250 \\
(195-270)\end{array}$ & $\begin{array}{c}470 \\
(412-511)\end{array}$ \\
\hline \multirow[t]{2}{*}{ Left Testicle } & Length & $200-960$ & $300-500$ & $\begin{array}{c}619 \\
(341-881)\end{array}$ & $\begin{array}{c}516 \\
(239-922)\end{array}$ & $\begin{array}{c}247 \\
(135-345)\end{array}$ & $\begin{array}{c}393 \\
(300-510)\end{array}$ & $\begin{array}{c}910 \\
(851-990)\end{array}$ \\
\hline & Width & $180-720$ & $250-780$ & $\begin{array}{c}400 \\
(239-580)\end{array}$ & $\begin{array}{c}356 \\
(184-642)\end{array}$ & $\begin{array}{c}199 \\
(135-345)\end{array}$ & $\begin{array}{c}250 \\
(195-270)\end{array}$ & $\begin{array}{c}515 \\
(465-549)\end{array}$ \\
\hline \multirow[t]{2}{*}{ Ovary } & Length & $90-540$ & $310-420$ & $\begin{array}{c}197 \\
(102-294)\end{array}$ & $\begin{array}{c}206 \\
(130-294)\end{array}$ & $\begin{array}{c}213 \\
(200-400)\end{array}$ & $\begin{array}{c}163 \\
(135-194)\end{array}$ & $\begin{array}{c}385 \\
(376-397)\end{array}$ \\
\hline & Width & $60-420$ & $420-520$ & $\begin{array}{c}294 \\
(171-389)\end{array}$ & $\begin{array}{c}284 \\
(171-430)\end{array}$ & $\begin{array}{c}252 \\
(130-274)\end{array}$ & $\begin{array}{c}163 \\
(135-194)\end{array}$ & $\begin{array}{c}281 \\
(241-338)\end{array}$ \\
\hline \multirow[t]{2}{*}{ Cirrus pouch } & Length & $420-540$ & $290-720$ & $\begin{array}{c}363 \\
(280-478)\end{array}$ & $\begin{array}{c}379 \\
(239-614)\end{array}$ & $\begin{array}{c}297 \\
(150-450)\end{array}$ & $\begin{array}{c}310 \\
(270-360)\end{array}$ & $\begin{array}{c}500 \\
(435-552)\end{array}$ \\
\hline & Width & 120 & $110-180$ & $\begin{array}{c}129 \\
(102-171)\end{array}$ & $\begin{array}{c}130 \\
(75-218)\end{array}$ & $\begin{array}{c}122 \\
(90-135)\end{array}$ & $\begin{array}{c}89 \\
(75-110)\end{array}$ & $\begin{array}{c}145 \\
(110-170)\end{array}$ \\
\hline \multicolumn{2}{|c|}{ References } & \multicolumn{2}{|c|}{ Travassos (1944) } & $\begin{array}{l}\text { Pinto et al. } \\
\text { (2016) }\end{array}$ & $\begin{array}{l}\text { Pinto et al. } \\
\text { (2017) }\end{array}$ & \multicolumn{2}{|c|}{$\begin{array}{c}\text { Kingston \& Cosgrove } \\
\text { (1967) }\end{array}$} & $\begin{array}{l}\text { Present } \\
\text { study }\end{array}$ \\
\hline
\end{tabular}

location in the biliary system and the fixation technique used may influence the dimensions of the internal structures used for specific morphological diagnosis. For those reasons, it is of value to consider that such morphological variations may explain the various reports of different species of Platynosomum in animals (Kingston \& Cosgrove, 1967; Sitko, 1998; Pinto et al., 2016), when, in fact, based on molecular analyses they were most likely the same species (Pinto et al., 2018).

The importance of members of the genus Platynosomum as parasites of captive, non-human primates of the genus Callithrix has been illustrated in numerous studies conducted in Brazil (Silva et al., 2012; Mati et al., 2015; Pinto et al., 2017, 2018; Pereira et al., 2021). However, with the exception of a single study (Pinto et al., 2018), molecular characterization was not used to corroborate the morphological identification of the parasites. As shown in the current study, sequence-based identification of ribosomal DNA can provide increased precision and 
confidence in the diagnosis of Platynosomum infections. Therefore, its use should be encouraged as a means to definitively determine the species that affect members of the genus Callithrix and other non-human primates in order to provide epidemiological data relevant to health surveillance. The possibility of applying existing molecular methods to monitor fecal samples, using DNA extracted from eggs, should also be investigated as a potential method for detecting asymptomatic infections and for determining the necessity for anti-parasitic treatments, including praziquantel, which in themselves may be detrimental to the health of marmosets (Mati et al., 2021).

Knowledge concerning physiopathology and the clinical manifestations of natural $P$. illiciens infections in nonhuman primates is inadequate. This deficiency results from the fact that most cases occurred as postmortem findings, based primarily upon the detection of adult trematodes in the liver and gall bladder, as in the present study. However, detailed histopathological data generated in two studies conducted by Brazilian primatologists (Sousa et al., 2008; Pereira et al., 2021) provided insight into the most common histopathological alterations and hepatobiliary disorders in different species of captive, non-human primates naturally parasitized by P. illiciens. Sousa et al. (2008) examined six common marmosets (Callithrix jacchus) suffering from severe non-diarrheic weight loss, and reported ascending cholangitis, cholestasis, and portal fibrosis that in some animals culminated in secondary biliary cirrhosis. In the more recent study, portal fibrosis, biliary epithelial hyperplasia, and inflammatory reactions with a predominance of lymphocytes and plasmocytes were considered the principal lesions and disorders encountered in 11 animals, classified by the authors as naturally infected with P. illiciens (Pereira et al., 2021).

In conclusion, contrary to reports of more than one species of Platynosomum as the etiological agent of platynosomiasis in non-human primates in Brazil, the morphological and molecular data presented herein provided a definitive diagnosis of parasitism by P. illiciens in a captive specimen of the genus Callithrix.

\section{Acknowledgements}

We would like to thank Letícia Gabriela Poblete Vidal for contributing to the measurement of specimens. This study was supported by the Support Foundation for Technological Research (Fundação de Apoio à Pesquisa Tecnológica, FAPUR) of the Federal Rural University of Rio de Janeiro, Coordination Office for Improvement of Higher-Education Personnel (Coordenação de Aperfeiçoamento Pessoal de Nível Superior, CAPES), Ministry of Education (Ministério da Educação, MEC) and the National Council for Scientific and Technological Development (Conselho Nacional de Desenvolvimento Científico e Tecnológico, CNPq).

\section{References}

Amato JFR, Boeger WA, Amato SB. Protocolos para laboratório - coleta e processamento de parasitos de pescado. Rio de Janeiro: Universidade Federal Rural do Rio de Janeiro; Edur; 1991.

Basu AK, Charles RA. A review of the cat liver fluke Platynosomum fastosum Kossack, 1910 (Trematoda: dicrocoeliidae). Vet Parasitol 2014; 200(1-2): 1-7. http://dx.doi.org/10.1016/j.vetpar.2013.12.016. PMid:24412358.

Bielsa LM, Greiner EC. Liver fluke (Platynosomum concinnum) in cats. J Am Anim Hosp Assoc 1985; 21: 269-274.

Kingston N, Cosgrove GE. Two new species of Platynosomum (Trematoda: Dicrocoeliidae) from South American monkeys. Proc Helminthol Soc Wash 1967; 34(2): 147-151.

Leal PDS, Campos DP, Rodrigues ML, Botelho GG, Labarthe NV, Lopes CWG. Parasitos gastrintestinais em uma colônia de gatos na Zona Oeste da cidade do Rio de Janeiro, Brasil. Braz J Vet Med 2015; 37(Supl. 1): 95-99.

Leal PDS, Campos DP, Rodrigues ML, Botelho GG, Labarthe NV. Avaliação da administração oral de ácido ursodesoxicólico (AUDC) no diagnóstico da infecção natural por Platynosomum illiciens em gatos. Braz J Vet Med 2011; 33(4): 229-233.

Lenis C, Navarro FJ, Velez I. First case of platinosomosis from Colombia: Platynosomum illiciens (Digenea: Dicrocoeliidae) in Felis catus, Turbo, Antioquia. Rev Colomb Cienc Pecua 2009; 22(4): 659-663.

Mati VL, Pinto HA, de Melo AL. Evaluation of Kato-Katz and spontaneous sedimentation methods for the diagnosis of platynosomiasis in Neotropical primates. Rev Bras Parasito/ Vet 2015; 24(1): 108-113. http://dx.doi.org/10.1590/S1984-29612015014. PMid:25909264.

Mati VLT, Pinto HA, de Melo AL. Treatment of primate platynosomosis: a word of caution about the use of praziquantel in marmosets. J Med Primatol 2021; 50(1): 60-66. http://dx.doi.org/10.1111/jmp.12503. PMid:33186482.

Nguyen HM, Van Hoang H, Ho LT. Platynosomum fastosum (Trematoda: Dicrocoeliidae) from cats in Vietnam: morphological redescription and molecular phylogenetics. Korean J Parasito/ 2017; 55(1): 39-45. https://doi.org/10.3347/kjp.2017.55.1.39. PMID: 28285505. 
Pereira WLA, Conga DMF, da Silva KSM, da Silva RJ, Imbeloni AA. Anatomopathological lesions of infection caused by Platynosomum illiciens (Braun, 1901) in Neotropical primates kept in captivity. J Med Primatol 2021; 50(1): 82-85. http://dx.doi.org/10.1111/ jmp.12504. PMid:33205447.

Pinto HA, Mati VL, de Melo AL. New insights into the life cycle of Platynosomum (Trematoda: dicrocoeliidae). Parasitol Res 2014; 113(7): 2701-2707. http://dx.doi.org/10.1007/s00436-014-3926-5. PMid:24802870.

Pinto HA, Mati VLT, Melo AL. Can the same species of Platynosomum (Trematoda: Dicrocoeliidae) infect both mammalian and avian hosts? J Helminthol 2016; 90(3): 372-376. http://dx.doi.org/10.1017/S0022149X15000152. PMid:25781630.

Pinto HA, Mati VLT, Melo AL. Experimental platynosomosis: characterization of parasite development in the mouse model. Vet Parasitol 2015; 211(1-2): 40-44. http://dx.doi.org/10.1016/j.vetpar.2015.04.021. PMid:25981104.

Pinto HA, Mati VLT, Pujoni DF, Melo AL. Platynosomum illiciens (Trematoda: Dicrocoeliidae) in captive black-tufted marmoset Callithrix penicillata (Primates: Cebidae) from Brazil: a morphometric analyses with taxonomic comments on species of Platynosomum from nonhuman primates. J Parasitol 2017; 103(1): 14-21. http://dx.doi.org/10.1645/16-1. PMid:27762668.

Pinto HA, Pulido-Murillo EA, Braga RR, Mati VL, Melo AL, Tkach VV. DNA sequences confirm low specificity to definitive host and wide distribution of the cat pathogen Platynosomum illiciens (= P. fastosum) (Trematoda: dicrocoeliidae). Parasitol Res 2018; 117(6): 1975-1978. http://dx.doi.org/10.1007/s00436-018-5866-y. PMid:29707742.

Ritchie LS. An ether sedimentation technique for routine stool examination. Bull U S Army Med Dep 1948; 8(4): 326. PMid:18911509.

Rodrigues HO. Contribuição ao estudo do gênero Platynosomum Looss, 1907: (Trematoda, Dicrocoeliidae). Mem Inst Oswaldo Cruz 1963; 61(3): 507-515. http://dx.doi.org/10.1590/S0074-02761963000300008. PMid:14141131.

Santolin ÍDAC, Famadas KM, McIntosh D. Detection and identification of Rickettsia agents in ticks collected from wild birds in Brazil by polymerase chain reaction-restriction fragment length polymorphism (PCR-RFLP) analysis. Braz J Vet Med 2013; 35(Supl. 2): 68-73.

Shell L, Ketzis J, Hall R, Rawlins G, du Plessis W. Praziquantel treatment for Platynosomum species infection of a domestic cat on St. Kitts, West Indies. JFMS Open Rep 2015; 1(1): 1-4. http://dx.doi.org/10.1177/2055116915589834. PMid:28491359.

Silva KSM, Silva RJ, Pereira WLA. Occurrence of infection by Platynosomum illiciens (Braun, 1901) in captive neotropical primates. Primates 2012; 53(1): 79-82. http://dx.doi.org/10.1007/s10329-011-0281-3. PMid:22071558.

Sitko J. Trematodes of birds of prey (Falconiformes) in Czech Republic. Helminthologia 1998; 35(3): $131-146$.

Sloss WM, Zajac MA, Kemp RL. Parasitologia clínica veterinária. 6. ed. São Paulo: Manole; 1999.

Sousa MB, Leão AC, Coutinho JF, de Oliveira Ramos AM. Histopathology findings in common marmosets (Callithrix jacchus Linnaeus, 1758) with chronic weight loss associated with bile tract obstruction by infestation with Platynosomum (Loos, 1907). Primates 2008; 49(4): 283-287. http://dx.doi.org/10.1007/s10329-008-0105-2. PMid:18841441.

Travassos L. Revisão da família Dicrocoeliidae Odhner, 1910. [Monografia] Rio de Janeiro: Instituto Oswaldo Cruz; 1944. 